\title{
PENGEMBANGAN KELOMPOK TANI YANG DINAMIS DALAM PENGEMBANGAN AGRIBISNIS HORTIKULTURA DI KOTA BATU
}

\author{
Acep Hariri ${ }^{1)}$, Sinta Dewi Andaru ${ }^{2)}$, dan Agus Suliyanto ${ }^{2)}$ \\ ${ }^{1)}$ Dosen STPP Malang \\ ${ }^{2)}$ Penyuluh Pertanian Kota Batu \\ Email : acep101984@gmail.com
}

\begin{abstract}
ABSTRAK
Pengembangan usaha tani yang berlandasan kerjasama perlu dilakukan pada petani negara berkembang. Pengembangan kelompok tani diharapkan mampu memperkuat pondasi ekonomi petani. Banyaknya petani yang berusaha sendiri menyebabkan mudahnya petani goyah dalam pelaksanaan usaha. Petani akan sulit menghadapi berbagai masalah ketika melakukan usaha sendiri. Kelompok sebagai wahana belajar, kerjasama dan produksi mampu memberikan banyak keuntungan bagi petani. Salah satu keuntungannya ialah melindungi petani dari kerugian usaha. Tujuan penelitian ini adalah untuk mengetahui peran kelompok tani yang dinamis dalam pengembangan agribisnis hortikultura. Penelitian dilaksanakan di Kota Batu Jawa Timur bulan Maret sampai dengan September 2017. Pendekatan yang digunakan dalam penelitian ini adalah kualitatif. Kelompok tani dapat dijadikan sebagai modal dalam pengembangan hortikultura. Kelompok mampu dijadikan sarana usaha agar lebih efektif dan efisien. Pelaksanaan agribisnis melalui kelompok banyak menguntungkan mempermudah usaha dan melindungi petani. Struktur dalam kelompok banyak yang sudah berjalan dengan menempatkan anggota sesuai dengan kompetensinya. Fungsi kelompok sebagai wahana belajar, kerjasama dan produksi sudah dinamis sehingga pelaksanaan usaha lebih mudah dan menguntungkan
\end{abstract}

Kata kunci : Kelompok tani, fungsi kelompok, pengembangan agribisnis hortikultura.

\section{ABSTRACT}

The development of cooperative farming business needs to be done in developing country farmers. The development of farmer groups is expected to strengthen the economic foundation of farmers. The number of self-employed farmers leads to the ease of unstable farmers in the conduct of business. Farmers will be difficult to face various problems when doing their own business. The group as a vehicle for learning, cooperation and production can provide many benefits for farmers. One of the advantages is protecting farmers from business losses. The purpose of this research is to know the role of dynamic farmer groups in the development of horticulture agribusiness. The research was conducted in Batu City of East Java from March to September 2017. The approach used in this research is qualitative. Farmer groups can be used as capital for horticulture development. The group can be used as a means of business to be more effective and efficient. The implementation of agribusiness through many beneficial groups facilitates business and protects farmers. Structures in many groups are already running by placing members according to their competence. The function of the group is learning, cooperation and production has been dynamic so that the implementation of business easier and profitable

Keyword : Farmer groups, group functions, horticultural agribusiness development 


\section{PENDAHULUAN}

Indonesia merupakan Negara agraris yang bertumpu pada sektor pertanian. pengembangan pertanian terus dilakukan oleh pemerintah melalui infrastruktur, bantuan dan pembinaan. Perbaikan sarana dan prasarana untuk menunjang keberhasilan pelaksanaan usaha tani. pemberian berbagai bantuan harus diimbangi dengan penguatan sumber daya manusia. Sebagian besar petani memiliki kebiasan hidup berkelompok. Petani akan mudah melakukan berbagai aktivitas usaha apabila dilakukan secara berkelompok.

Kelompok yang merupakan wahana belajar bersama antar petani memiliki banyak peranan dalam pengembangan agribisnis hortikultura. Kelompok sebagai wahana belajar dapat digunakan untuk belajar bersama dalam memecahkan berbagai masalah. Kelompok dapat digunakan sebagai wahana untuk saling bertukar pendapat dan saling menolong ketika mengalami masalah atau kendala. Kelompok dapat digunakan sebagai fasilitas pengembangan usaha. Melalui kelompok tani, anggota dapat melakukan berbagai usaha terutama fasilitas dalam melancarkan pelaksanaan usaha.

Pemanfaatan kelompok selama ini sebatas sebagai sarana pertemuan untuk menjalin silaturahmi, padahal kelompok memiliki banyak manfaat terutama dalam pengembangan agribisnis. Pengelolaan usaha tani melalui kelompok lebih efektif dan efisien terutama dalam segi pemasaran. Pengadaan sarana produksi yang dilakukan secara bersamaan dapat mempermudah akses petani dalam mengadakan sarana produksi. Kelompok saat ini banyak digunakan sebagai media untuk menerima bantuan sehingga motivasi petani terlibat dalam kelompok untuk menerima bantuan. Dampak kejadian ini banyak anggota yang terlibat penuh dan setiap pertemuan tidak hadir. Hal ini menyebabkan kegiatan kelompok tidak berjalan. Tujuan penelitian ini adalah untuk menganalasis suatu kelompok tani yang dinamis sebagai proses belajar, kerjasama dan usaha dalam pengembangan agribisnis hortikultura.

\section{METODE PENELITIAN}

\section{Waktu dan Lokasi Penelitian}

Pelaksanaan penelitian dilaksanakan pada bulan Maret s/d September 2017 berlokasi di Kota Batu Jawa Timur

\section{Pendekatan}

Berdasarkan rumusan masalah dan tujuan penelitian yang hendak dicapai, penelitian ini dilakukan dengan menggunakan pendekatan kualitatif. Analisis kualitatif digunakan untuk mengungkap fenomena dan makna yang ada pada kelompoktani akan proses dinamika yang terjadi sehingga mampu mengembangkan agribsinis.

\section{Informan}

Dalam penelitian ini penentuan informan ditentukan secara sengaja (purpossive) sesuai dengan penelitian tentang dinamika kelompok dalam pengembangan agribisnis hortikultura di Kota Batu. Sumber data digali dari Dinas Pertanian, Penyuluh pertanian, ketua gabungan kelompoktani, anggota kelompoktani. Informan dalam penelitian ini adalah ketua gapoktan, ketua kelompok tani, anggota kelompok tani dan penyuluh. Peneliti melalukan wawancara secara mendalam terhadap para informan yang telah dipilih secara selektif.

\section{Teknik Pengumpulan Data}

Ada beberapa teknik yang diterapkan dalam mengumpulkan data yang diperlukan dalam penelitian ini, yaitu:

1. Wawancara mendalam

Wawancara yang dilakukan secara semi terstruktur, yaitu struktur wawancara tidak terlalu ketat, lebih fleksibel mengenai urutan topik yang dibahas.

2. Pengamatan partisipan (Paticipant Observation)

Observasi dilakukan secara langsung pada obyek penelitian. Waktu observasi peneliti adalah saat melakukan wawancara sambil mengamati sekeliling dengan seksama.

3. Focus Group Discussion (FGD) 
Pada tahap ini dilakukan pertemuan antara ketua gapoktan, anggota dan penyuluh pertanian.

\section{Teknik Analisis Data}

Teknik analisis data kualitatif yang digunakan dalam penelitian ini adalah model interaktif seperti yang dikemukakan oleh Miles dan Huberman (1992). Model ini terdiri dari tiga hal pokok yaitu reduksi data, penyajian data dan penarikan kesimpulan. Ketiga hal ini saling jalin menjalin pada saat, selama dan setelah pengumpulan data dilakukan sehingga seakan-akan membentuk siklus yang interaktif. Adapun triangulasi yang digunakan ialah triangulasi waktu dan sumber.

\section{Keabsahan}

Menurut Moleong (2000) dalam penelitian kualitatif ini memakai 3 macam keabsahan data yaitu:

\section{Kepercayaan (creadibility)}

Kreadibilitas data dimaksudkan untuk membuktikan data yang berhasil dikumpulkan sesuai dengan sebenarnya. Ada beberapa teknik untuk mencapai kreadibilitas ialah teknik triangulasi, sumber, pengecekan anggota, perpanjangan kehadiran peneliti dilapangan, diskusi teman sejawat, dan pengecekan kecakupan refrensi.

\section{Kebergantungan (dependibility)}

Kriteria ini digunakan untuk menjaga kehatihatian akan terjadinya kemungkinan kesalahan dalam mengumpulkan dan menginterprestasikan data sehingga data dapat dipertanggungjawabkan secara ilmiah

3. Kepastian (confermability)

Kriteria ini digunakan untuk menilai hasil penelitian yang dilakukan dengan cara mengecek data dan informasi serta interpretasi hasil penelitian yang didukung oleh materi yang ada pada pelacakan audit.

\section{HASIL DAN PEMBAHASAN}

\section{Kelompok Tani Modal dalam Agribisnis Hortikultura}

Dalam kamus besar bahasa Indonesia agribisnis adalah rangkaian kegiatan usaha dalam bidang pertanian mulai produksi, panen dan pasca panen. Hal ini sesuai dengan pendapat Sjarkowi dan Sufri (2004) agribisnis adalah setiap kegiatan usaha yang berkaitan dengan kegiatan produksi pertanian meliputi input, produksi dan pengolahan hasil pertanian. Kegiatan agribisnis akan berhasil ketika berbagai aspek dalam usaha hortikultura mampu dilakukan dengan baik.

Pelaksanaan usaha petani banyak mengandalkan sendiri-sendiri terutama sektor hortikultura. Pelaksanaan usaha secara bersama-sama sangat menguntungkan tidak terjadinya persaingan yang tidak sehat yang saling menjatuhkan. Pelaksanaan usaha tani model kerjasama dilakukan melalui kelompok tani.

Menurut Johnson (2012) kelompok dapat diartikan sebagai sejumlah orang yang berkumpul bersama untuk mencapai suatu tujuan. Kelompok terbentuk untuk mencapai tujuan bersama sehingga dalam pelaksanaannya dilakukan bersama-sama. Pelaksanaan usaha melalui kelompok banyak menguntungkan. Salah satu upaya ialah melalui toko tani dalam menyediakan sarana produksi usaha. Petani mendapatkan harga yang murah serta tidak sulit mencari kebutuhan sarana produksi usaha. Kelompok mampu dijadikan sarana untuk melakukan pemasaran bersama. Banyak kelompok yang sudah memfasilitasi pemasaran produk hortikultura mulai memfasilitasi akses pasar, transportasi bersama, pengolahan maupun pengaturan harga. Berbagai cara dalam kelompok dilakukan oleh semua anggota kelompok. Berbagai permasalahan usaha tani dapat dipecahkan dalam kelompok. Hal ini menyebabkan kelompok tani mudal yang sangat penting dalam usaha tani untuk mewujudkan petani yang sejahtera. 


\section{Kelompok Tani Sebagai Sarana Pengembangan Usaha}

Kelompok banyak digunakan sebagai sarana dalam pengembangan usaha hortikultura. Kasimin (2013) dalam penelitiannya menyatakan tingkat pendapatan hortikultura unggulan dipengaruhi oleh harga jual, biaya pemasaran, pola pembinaan, dan sarana transportasi. Pembinaan dilakukan melalui kelompok tani. Kelompok banyak digunakan sebagai sarana uji coba usaha. Pelaksanaan usaha bersama dalam kelompok tani memiliki banyak jenis diantaranya lahan usaha bersama, toko tani maupun asosiasi. Pada hakikatnya kelompok tani melindungi anggotanya dari permainan usaha. Banyak petani yang mengalami keuntungan dengan ikut kelompok seperti pernyataan pak SG (Anggota kelompok tani) menyampaikan

"kelompok banyak memberikan
perlindungan pada petani seperti melindungi
dari harga yang jatuh. Kelompok mengatur
harga yang harus dijual oleh petani dan
harga yang harus dibayar oleh pembeli. Jika
kami melanggar akan kena teguran dari
kelompok. selain itu kelompok banyak
memberikan ilmu dalam pengembangan
usaha diantaranya perbaikan teknologi agar
usaha lebih menguntungkan".

Berdasarkan pernyataan tersebut kelompok mampu hadir dalam melindungi petani. Petani terlibat dalam kelompok karena merasa mendapat manfaat sebagai anggota. Manfaat yang diterima ialah mendapatkan ilmu dalam perbaikan usaha. Perbaikan teknik usaha didapat dengan adanya penyampaian informasi oleh penyuluh maupun pihak lain yang banyak difasilitasi oleh kelompok tani. perbaikan usaha untuk menyesuaikan dengan kondisi saat ini. Pemasaran yang selama ini menjadi kendala akibat saling menjatuhkan harga dikelola oleh kelompok. Kerjasama pelaku usaha dan kelompok tani menjadi kunci pemecahan saling menjatuhkan harga. Pembeli dan petani menjual harga yang telah disepakat dan tidak boleh melanggar. Harga yang disepakati adalah harga paling rendah sehingga yang membeli produk hortikultura harus mematuhinya. Kasus sudah diterapkan petani tanaman hias dengan mematok harga minimal Rp. 1.000,- pertangkai dan harus dipatuhi oleh semua petani.

Banyak pola pikir yang berubah setelah pelaksanaan usaha tani. seperti pernyataan $\mathrm{Bu}$ LBN (Ketua kelompok wanita tani)

"sebelum ada kelompok ibu-ibu bingung mau melakukan usaha apalagi kemampuan kami sangat pas-pasan. Adanya kelompok dan pembinaan oleh pemerintah akhirnya kami banyak mendapat ilmu. Kami mulai mengetahu cara berusaha tani dengan cara olahan, pengemasan dan pemasaran meskipun saat ini pemasaran dilakukan melalui mulut ke mulut akan tetapi dengan ikut kelompok kami mulai memperhatikan kualitas produk agar laku dipasaran"

Berdasarkan pernyataan tersebut kelompok memiliki peranan dalam membangun kepercayaan usaha tani petani. Awalnya yang tidak memiliki kemampuan dalam melakukan usaha dengan adanya kelompok dapat fasilitas berupa bimbingan dan kerjasama sehingga saling bertukar informasi. Setiap anggota memiliki kesempatan yang sama untuk mengembangkan usaha. Pengembangan tidak lepas dari pembinaan yang dilakukan oleh penyuluh maupun pemerintah pada kelompok tani. pembinaan pada kelompok tani dianggap lebih efektif karena anggota dapat merembeskan informasi pada petani yang lainnya khususnya sesama anggota umumnya pada petani yang lainnya.

\section{Struktur Kelompok Tani}

Menjalankan struktur kelompok tani berarti sebuah kelompok mampu menjalankan kelompok berdasarkan potensi yang dimiliki. Potensi yang dimiliki dapat berupa pisik maupun sumber daya lainnya. Potensi yang ada pada kelompok dapat membentuk sebuah pola hubungan yang saling menguntungkan dan memberikan tanggung jawab dinatara anggota kelompok tani. Semua anggota memiliki hak dan kewajiban yang sama sebagai bahan pertimbangan pengembangan kelompok tani.

Kelompok tani di Kota Batu sebagian besar sudah menjalankan struktur sesuai dengan kebutuhan. Kelompok memperhatikan 
kompetensi anggot dalam menjalankan struktur kelompok. anggota ditugaskan sesuai dengan kemampuan yang dimiliki selain itu kelompok yang tidak memiliki kompetensi akan diajarkan oleh anggota lain yang sudah memiliki kemampuan. Saling tukar tugas sangat banyak memberikan warna dalam menjalankan kelompok tani. Semua anggota memiliki kesempatan yang sama untuk pengembangan diri. Seperti pernyataan pak SS (Anggota kelompok tani).

"kelompok di sini (Desa Punten) sudah menempatkan anggota dalam seksi sesuai dengan kemampuannya. Seksi pengembangan jeruk ditempati oleh anggota yang menguasai budidaya jeruk. Sama halnya juga dengan bagian apel, anggota yang bertanggung jawab dalam seksi pengembangan apel anggota yang sukses dalam budidaya apel. Seksi pemasaran juga ditempati yang sering bekerja menjadi tengkulak (rangkap sebagai petani dan penjual produk hortikultura). Hal ini dilakukan untuk mempermudah pelaksanaan tugas dan hasilnya lebih berhasil. Penempatan orang yang mahir di bidangnya akan lebih memudahkan pelaksanaan tugas kelompok sehingga ketua tidak terlalu berat melaksanakan tugasnya. Ini juga sebagai bentuk kerjasama dalam kelompok".

Berdasarkan pernyataan tersebut kelompok sudah melihat potensi yang dimiliki setiap anggota. Potensi dimanfaatkan dalam menjalankan kelompok tani. Pemanfaatan potensi dilakukan untuk mempermudah menjalankan kelompok tani seperti penempatan anggota kelompok dalam struktur organisasi kelompok. Kelompok melakukan evaluasi terhadap jalannya kelompok tani. Evaluasi dilakukan setiap pertemuan rutin yang dilakukan setiap satu bulan. Evaluasi dilakukan untuk memperbaiki kesalahan atau memecahkan kendala yang dihadapi. Evaluasi dilakukan supaya semua anggota tahu perkembangan usaha dalam kelompok tani. Saling terbuka diantara anggota kelompok untuk menghindari banyak terjadi konplik dan saling curiga.

Selain rasa terbuka, rasa kebersamaan dalam kelompok dibentuk dengan sistem kekeluargaan. Hal ini menyebabkan aturan hukuman bagi anggota kelompok yang tidak aktif tidak terlihat jelas. Pelaksanaan norma banyak tidak berjalan dengan baik. Padahal norma yang akan mengontrol terhadap pelaksanaan kelompok tani. norma mengatur terhadap aturan yang sudah disepakati bersama. Menurut Umstot (1988) Norma adalah harapan yang diaplikasikan untuk semua anggota kelompok. Norma akan banyak mengontrol supaya anggota melaksanakan kesepakatan yang sudah disepakati bersama. Apabila ada anggota yang melanggar harus menerima hukuman dan anggota yang aktif menerima reward dari kelompok tani. Penerapan norma diharapkan dapat menajga keutuhan kelompok tani.

\section{Menjalankan Fungsi Kelompok}

Fungsi kelompok tani ada tiga yaitu sebagai proses belajar, proses kerjasama dan unit produksi. Berjalan atau tidak fungsi kelompok tergantung kelompok itu sendiri. Pelaksanaan fungsi mulai perencanaan, pelaksanaan maupun evaluasi. Fungsi kelompok yang dinamis akan lebih mudah kelompok dalam melakukan pembinaan terhadap pengembangan usaha. Pembinaan dilakukan agar usaha hortikultura yang dilakukan menguntungkan dan mampu menolong dirinya dan orang lain.

Fungsi kelompok sebagai wahana belajar untuk saling tukar informasi dalam memecahkan masalah. Banyak petani yang merubah teknik usaha setelah masuk dalam kelompok. Salah satunya petani apel dalam mengelola kebun apel. Sebelum adanya kelompok petani merawat apel sesuai dengan apa adanya sehingga produksinya tidak optimal. Setelah terlibat dalam kelompok dan menerima berbagai ilmu dalam kelompok mampu memperbaiki usaha tani. Perbaikan yang dilakukan ialah mulai memperhatikan pemupukan, pengendalian hama dan penyakit serta pemangkasan. Hasil yang didapat produksinya lebih optimal. Wahana belajar yang dibangun pada kelompok ialah bagaimana memecahkan masalah yang dihadapi. Proses belajar dalam kelompok dilakukan oleh penyuluh dan kelompok tani sendiri. 
Pemecahan masalah dapat dilakukan oleh kelompok maupun dengan melibatkan pihak lain.

Komunikasi yang dibangun ialah sistem kerjasama. Segala permasalahan yang dihadapi oleh anggota akan dipecahkan secara bersamasama oleh seluruh anggota kelompok. Wahana kerjasama dibangun untuk mempermudah pelaksanaan usaha tani. Adanya kerjasama dapat saling membantu mulai pengadaan sarana produksi sampai pemasaran. Wahana kerjasama juga dapat saling memberi informasi terkait keberhasilan usaha.

Fungsi selanjutnya ialah sebagai wahana untuk produksi hortikultura. Kelompok digunakan sebagai wahana kerjasama dalam menghasilkan produk hortikultura baik kuantitas dan kualitas. Menghasilkan produk hortikultura adalah upaya untuk memenuhi kebutuhan keluarga tani. kelompok tani memfasilitasi mulai sistem belajar maupun kerjasama. Belajar bagaimana menghasilkan produk hortikultura yang menguntungkan serta kerjasama dalam pelaksanaan usaha. Keberhasilan kelompok sangat besar pengaruhnya dalam pelaksanaan usaha tani anggota kelompok. Kelompok yang dinamis mampu membangun suasana usaha yang kondusip serta mampu melindungi petani dari kerugian. Kelompok yang dinamis mampu membantu petani dalam mewujudkan kesejahterannya.

\section{KESIMPULAN DAN SARAN}

Adapun kesimpulan dalam penelitian ini adalah bahwa pelaksanaan usaha melalui kelompok tani banyak memberikan keuntungan mulai sarana produksi, pelaksanaan usaha sampai pemasaran hasil. Kelompok dapat dijadikan sebagai sarana dalam pengembangan usaha tani dalam upaya membantu memecahkan masalah yang dihadapi oleh petani. Struktur dalam kelompok banyak yang sudah berjalan dengan menempatkan anggota sesuai dengan kompetensinya. Fungsi kelompok sebagai wahana belajar, kerjasama dan produksi sudah dinamis sehingga pelaksanaan usaha lebih mudah dan menguntungkan. Saran dalam pengembangan kelompok yang dinamis adalah penerapan norma. Sebagian besar kelompok belum mampu menerapkan norma dengan baik padahal norma yang mengatur aturan yang sudah disepakati bersama.

\section{DAFTAR PUSTAKA}

Johnson, D.W dan Johnson, F.P. 2012. Dinamika Kelompok Edisi Sembilan Teori dan Keterampilan : Edisi Bahasa Indonesia. Jakarta : PT. Indeks.

Kasimin,S. 2013. Keterkaitan Produk dan Pelaku dalam Pengembangan Agribisnis Hortikultura Unggulan di Provinsi Aceh. Jurnal Manajemen \& Agribisnis IPB, Vol. 10 No. 2, Juli 2013

Miles. M.B dan Huberman A.M. 1992. Analisis Data Kualitatif. Jakarta : Universitas Indonesia (UI-Press)

Moleong, Lexy J. 2000. Metodologi Penelitian Kualitatif. Bandung : Remaja Rosdakarya

Santosa, S. 2004. Dinamika Kelompok. Jakarta : Bumi Aksara.

Severino, S dan Messina, R. 2011. Group Dynamics in On-Line and Face-toFace Interactions: An Experimental Study on Learning Methods. Sociology Mind Volume 1 No. 2 Tahun 2011

Thoha, M. 2012. Perilaku Organisasi Konsep Dasar dan Aplikasinya. Jakarta : Raja Grafindo Persada. 
Pengembangan Kelompok Tani yang Dinamis

(Acep Hariri, Sinta Dewi Andaru dan Agus Suliyanto)

Umstot. 1988. Understanding Organizational

Behavior. New York : West Publishing Company

Syarkowi, F. \& Sufri. 2004. Manajemen

Agribisnis. Palembang : CV.

Baldal Grafiti Pres. 